\title{
In situ formation of nanocrystals from a self-microemulsifying drug delivery system to enhance oral bioavailability of fenofibrate
}

This article was published in the following Dove Press journal:

International Journal of Nanomedicine

18 October 2011

Number of times this article has been viewed

\author{
You-Meei Lin' \\ Jui-Yu Wu² \\ Ying-Chen Chen ${ }^{3}$ \\ Yu-Der $\mathrm{Su}^{3}$ \\ Wen-Tin $\mathrm{Ke}^{3}$ \\ $\mathrm{Hsiu}-\mathrm{O} \mathrm{\textrm {Ho } ^ { 3 }}$ \\ Ming-Thau Sheu ${ }^{3}$ \\ 'Department of Pharmacy, Shuang \\ Ho Hospital, ${ }^{2}$ Department of \\ Biochemistry, School of Medicine, \\ ${ }^{3}$ School of Pharmacy, College of \\ Pharmacy, Taipei Medical University, \\ Taipei, Taiwan, ROC
}

Objectives: In situ formation of nanocrystals and dissolution profiles of fenofibrate (FFB) from a self-microemulsifying drug delivery system (SMEDDS) were characterized.

Methods: SMEDDS formulated with $\mathrm{Myritol}^{\circledR}$ and surfactant mixture $\left(\mathrm{S}_{\text {mix }}\right)$ of D- $\alpha$-Tocopheryl polyethylene glycol 1000 succinate (TPGS) and either Tween ${ }^{\circledR} 20$ (A, C, E, G, M, S, N, T, O)

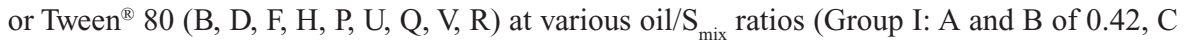
and $\mathrm{D}$ of 0.25 , E and F of 0.11 ; Group II: $\mathrm{G}$ and $\mathrm{H}$ of $1.38, \mathrm{M}$ and $\mathrm{P}$ of $1.11, \mathrm{~S}$ and $\mathrm{U}$ of $0.9, \mathrm{~N}$ and $\mathrm{Q}$ of $0.73, \mathrm{~T}$ and $\mathrm{V}$ of 0.58 , and $\mathrm{O}$ and $\mathrm{R}$ of 0.46$)$ and water contents (1: 9.5\%, 2: $5.0 \%, 3$ : $0.0 \%, \mathrm{G}-\mathrm{V}: 4.5 \%)$. Their dissolutions were conducted at different rotation speeds. Two optimal SMEDDSs containing Tween $80(\mathrm{~B} 2)$ or a higher oil/ $\mathrm{S}_{\text {mix }}$ ratio(Q) and B2(solution) were selected for pharmacokinetic study.

Results: FFB particles formed within the nanosize range from Group I gradually increased with time but decreased with increasing stirring rates. However, the mean size of FFB formed by $B$ series was as low as $200 \mathrm{~nm}$, which was smaller than that of A series at three stirring rates. The release rate from both groups obviously increased with increasing stirring rate. However, incomplete release was observed for $\mathrm{S}$ and $\mathrm{N}$ in Tween 20 series, whereas a faster release rate and complete release were observed for Tween 80 series with an insignificant difference among them. Results of pharmacokinetic study demonstrated that the highest-ranked area under the curve and $\mathrm{C}_{\max }$ values were for Q(SMEDDS) and B2(solution), respectively. The relative bioavailability of Q(SMEDDS) with respect to Tricor ${ }^{\circledR}$ was enhanced by about 1.14-1.22-fold.

Conclusion: SMEDDS, consisting of Myritol 318 and TPGS combined with Tween 80 at 4:1, was able to enhance the oral bioavailability of FFB.

Keywords: SMEDDS, fenofibrate, microemulsion, dissolution, TPGS

\section{Introduction}

Since microemulsions were first introduced some 60 years ago by Hoar and Schuaman, ${ }^{1}$ many applications have been found, especially for improving the oral bioavailability of poorly soluble drugs and nutraceuticals. ${ }^{2}$ Currently, water/oil (w/o) types of microemulsions, ${ }^{3}$ or oil/water $(\mathrm{o} / \mathrm{w})$ microemulsions separated by a two-phase region, ${ }^{4,5}$ self-microemulsifying drug delivery system (SMEDDS), ${ }^{6-8}$ and U-type phase diagrams capable of forming microemulsions at any given water dilution level (U-type preconcentrate) have been utilized to solubilize and increase the bioavailability of drugs and nutraceuticals. ${ }^{9-13} \mathrm{~W} / \mathrm{o}$ or $\mathrm{o} / \mathrm{W}$ microemulsions are excellent and effective carriers that increase the solubility and improve the bioavailability of poorly water-soluble drugs. ${ }^{14}$ Optimally, SMEDDSs and U-type preconcentrate are clear and transparent isotropic systems, which have the ability to produce o/w microemulsion systems when 
in contact with aqueous media (ie, the gastrointestinal fluid) under gentle agitation (ie, digestive motility of the stomach and intestines), which would be advantageous in resolving the problem of the deterioration of soft capsules due to the water content of either w/o or o/w type microemulsions. ${ }^{15,16}$

A SMEDDS is used to form preconcentrates of surfactants, oil, cosolvents, so that the drug can be diluted with water or $\mathrm{pH} 1.2$ simulated gastric acid when orally administered to form $\mathrm{o} / \mathrm{W}$ microemulsions with droplet sizes within the nanosize range. Nanosized droplets formed this way have very high surface-to-volume ratios and are expected to solubilize the drug, speed up drug release, and, subsequently, improve the bioavailability ${ }^{17}$ as well as release the drug in a more reproducible manner, which is less dependent on the gastrointestinal physiology and feeding/ fasting state of the patient. ${ }^{18}$ SMEDDSs have been reported to improve the in vivo dissolution and therefore enhance the bioavailability of lipophilic drugs. ${ }^{6,19-25}$ Commercially available drugs that make use of SMEDDSs include cyclosporin A as well as preparations of ritonavir and saquinavir (HIV protease inhibitors). ${ }^{26,27}$ However, although the SMEDDS preconcentrates containing $10 \%$ celecoxib revealed by Subramanian et al were not fully dilutable and only formed fine o/w droplets upon dilution in an aqueous phase, the results of drug absorption in humans were very encouraging, with a 1.32-fold increase in the relative bioavailability compared with a conventional dosage form. ${ }^{28}$ Moreover, unlike drug-free SMEDDS preconcentrates, when flurbiprofen was loaded, the dilution mixtures generated by the SMEDDS preconcentrates containing either Tween ${ }^{\circledR}$ 20 (ICI Americas Inc, Wilmington, DE) or Cremophor ${ }^{\circledR}$ EL (BASF Corp, Ludwigshafen, Germany) with Capmul ${ }^{\circledR}$ PG8 (ABITEC Corp, Columbus, OH) produced emulsions with observed cloudiness, the particle size was greatly increased compared with that of drug-free microemulsions ( 11-13 nm). ${ }^{29}$ This effect became more apparent as the drug loading was increased.

Fenofibrate (FFB), used to treat high-cholesterol and high-triglyceride levels, is a neutral lipophilic compound $(\log P=5.24)$ with very low solubility $(<0.5 \mathrm{mg} / \mathrm{L}) .{ }^{30}$ A low dissolution rate in aqueous media (including gastrointestinal fluids) is expected, which will result in incomplete and irregular bioavailability after oral ingestion. Reduction in the particle size of FFB by a micronization process can improve its solubility and the bioavailability is subsequently increased. ${ }^{30}$ A new dosage form of FFB, called a suprabioavailable tablet, has been developed, which combines micronization technology and microcoating processes. In this way, the increase in the amount of drug dissolved in the aqueous medium of the gastrointestinal tract also improves the extent of absorption. ${ }^{31-33}$ Another type of formulation developed for FFB is a hard gelatin capsule with a semisolid content into which FFB is homogenously dispersed within a lipid excipient mixture supplemented with hydroxypropyl methyl cellulose. The resulting formulation has increased drug solubility and dissolution rates as well as improved oral bioavailability equivalent to micronized FFB formulations. ${ }^{34}$

A SMEDDS composed of Labrafac ${ }^{\mathrm{TM}}$ (Gattefossé, Lyon, France) CM10 (31.5\%), Tween ${ }^{\circledR} 80$ (ICI Americas Inc) (47.3\%), and polyethylene glycol 400 (12.7\%) was formulated for FFB and produced significant reductions in serum lipid levels in Phases I and II of the Triton test compared with plain FFB. ${ }^{35}$ Based on the previous study, ${ }^{36}$ the authors of the present study were intrigued that microemulsifying SMEDDSs in an aqueous medium or gastrointestinal tract fluid could decrease the drug loading, causing the solubilized FFB in the SMEDDS preconcentrate to precipitate. The authors wished to characterize how formulation factors of SMEDDSs affected the resultant drug particles for dissolution after microemulsification with aqueous medium or gastrointestinal tract fluid, which influenced the in vivo absorption. Thus, the main objective of this study was to characterize the in situ formation of nanocrystals and dissolution profiles of FFB from SMEDDSs containing an oil of medium-chain triglyceride (MCT), Myritol ${ }^{\circledR}$ 318, and nonionic surfactant mixture, D- $\alpha$-tocopheryl polyethylene glycol 1000 succinate (TPGS) combined with Tweens for a lipophilic model drug, FFB, in terms of the formulation factors and dissolution conditions to optimally correlate them with in vivo oral absorption.

\section{Experimental}

\section{Materials}

Myritol 318 ( $\mathrm{C}_{8} / \mathrm{C}_{10}$ triglycerides) (Cognis Ltd, Tokyo, Japan) was used as the oil phase. TPGS was purchased from Eastman Chemical Company (Kingsport, TN, USA). FFB and fenofibric acid (FBA) were supplied from Sigma Aldrich (St Louis, MO). Tween 20 and 80 were purchased from E Merck (Darmstadt, Germany). Hard gelatin capsules were supplied by Shing Lih Fang Enterprise (Taichung, Taiwan). Tricor $^{\circledR} 54$ mg tablets (lot 028362E21; exp date 2005/03/01) were supplied by Abbott Laboratories (North Chicago, IL; manufactured by Laboratories Fournier, Chenôve, France). All materials were either pharmaceutical or reagent grade. 


\section{Preparation and viscosity measurement of SMEDDS}

The pseudoternary phase diagrams of the SMEDDSs constructed previously ${ }^{14}$ comprised Myritol 318 and surfactant mixtures $\left(\mathrm{S}_{\text {mix }}\right.$ ) of TPGS/polysorbates (Tween 20 or 80 ), incorporating 10\% FFB. Formulations for the SMEDDSs, either within or outside the microemulsion region, were selected; their preliminary physical characteristics are listed in Tables 1 and 2, respectively. The formulation components were accurately weighed into screw-capped glass tubes with water-tight closures and heated to approximately $80^{\circ} \mathrm{C}$ in a thermostat-controlled water bath. When all formulation components had been melted/liquefied, the mixtures were thoroughly vortex mixed until a homogeneous solution was obtained, which was then allowed to stand at room temperature. The viscosity of the SMEDDSs was measured with a viscometer (model DV-II+ viscometer, Brookfield Engineering Labs, Middleboro, MA) using an LV spindle set of $\operatorname{sp} 16$ at $37^{\circ} \mathrm{C}$. The mixture of the SMEDDS was manually filled into size 1 transparent hard gelatin capsules

Table I Formulation compositions and physical characteristics (appearance, mean particle size, and polydispersity index) of fenofibrate (FFB) self-microemulsifying drug delivery system (SMEDDS) composed of $D$ - $\alpha$-tocopheryl polyethylene glycol I000 succinate (TPGS) as the surfactant and Tween ${ }^{\circledR} 20(\mathrm{~A}, \mathrm{C}$, and $\mathrm{E})$ or $\operatorname{Tw}{ }^{\circledR}{ }^{\circledR} 80(\mathrm{~B}, \mathrm{D}$, and $\mathrm{F})$ as the cosurfactant at various oil/S mix ratios $(\mathrm{A}$ and $\mathrm{B}$ at 0.42 , $\mathrm{C}$ and $\mathrm{D}$ at 0.25 , and $\mathrm{E}$ and $\mathrm{F}$ at $0 . \mathrm{II})$ and water contents $(-\mathrm{I},-2$, and -3$)$

\begin{tabular}{|c|c|c|c|c|c|c|c|c|c|}
\hline \multirow[t]{2}{*}{ Code } & \multirow{2}{*}{$\begin{array}{l}\text { Myritol }^{\circledR} \\
318(\mathrm{mg})\end{array}$} & \multirow{2}{*}{$\begin{array}{l}\text { TPGS/ } \\
\text { Tween } 20 \\
(\mathbf{m g})^{\mathrm{a}}\end{array}$} & \multirow{2}{*}{$\begin{array}{l}\text { TPGS/ } \\
\text { Tween } 80 \\
(\mathbf{m g})^{a}\end{array}$} & \multirow{2}{*}{$\begin{array}{l}\mathrm{H}_{2} \mathrm{O} \\
(\mu \mathrm{g})\end{array}$} & \multicolumn{2}{|l|}{ Appearance } & \multicolumn{3}{|c|}{ Particle size (nm, PI) } \\
\hline & & & & & $12 \mathrm{~h}$ & I week & 10 rpm & 25 rpm & $50 \mathrm{rpm}$ \\
\hline Al & $\begin{array}{l}135.0 \\
(23.8 \%)\end{array}$ & $\begin{array}{l}324.0 \\
(57.1 \%)\end{array}$ & - & $\begin{array}{l}54.0 \\
(9.5 \%)\end{array}$ & $\mathrm{D}, \mathrm{C}$ & PPT $\left(+++^{*}\right)$, C & $\begin{array}{l}351.2 \pm 7.7 \\
(0.168 \pm 0.027)\end{array}$ & $\begin{array}{l}352.3 \pm 7.8 \\
(0.206 \pm 0.031)\end{array}$ & $\begin{array}{l}267.3 \pm 3.1 \\
(0.130 \pm 0.027)\end{array}$ \\
\hline A2 & $\begin{array}{l}135.0 \\
(25.0 \%)\end{array}$ & $\begin{array}{l}324.0 \\
(60.0 \%)\end{array}$ & - & $\begin{array}{l}27.0 \\
(5.0 \%)\end{array}$ & $D, C$ & PPT(+++), C & $\begin{array}{l}370.6 \pm 15.1 \\
(0.259 \pm 0.031)\end{array}$ & $\begin{array}{l}372.5 \pm 6.7 \\
(0.251 \pm 0.024)\end{array}$ & $\begin{array}{l}258.0 \pm 3.9 \\
(0.143 \pm 0.033)\end{array}$ \\
\hline A3 & $\begin{array}{l}135.0 \\
(26.3 \%)\end{array}$ & $\begin{array}{l}324.0 \\
(63.2 \%)\end{array}$ & - & $\begin{array}{l}0.0 \\
(0.0 \%)\end{array}$ & $D, C$ & $\operatorname{PPT}\left(++^{*}\right), \mathrm{C}$ & $\begin{array}{l}373.6 \pm 6.1 \\
(0.236 \pm 0.028)\end{array}$ & $\begin{array}{l}365.1 \pm 6.4 \\
(0.188 \pm 0.038)\end{array}$ & $\begin{array}{l}291.0 \pm 4.0 \\
(0.202 \pm 0.023)\end{array}$ \\
\hline BI & $\begin{array}{l}135.0 \\
(23.8 \%)\end{array}$ & - & $\begin{array}{l}324.0 \\
(57.1 \%)\end{array}$ & $\begin{array}{l}54.0 \\
(9.5 \%)\end{array}$ & $D, C$ & $\operatorname{PPT}\left(++^{*}\right), \mathrm{C}$ & $\begin{array}{l}245.5 \pm 3.9 \\
(0.124 \pm 0.032)\end{array}$ & $\begin{array}{l}209.8 \pm 2.7 \\
(0.098 \pm 0.038)\end{array}$ & $\begin{array}{l}190.1 \pm 3.9 \\
(0.126 \pm 0.029)\end{array}$ \\
\hline B2 & $\begin{array}{l}135.0 \\
(25.0 \%)\end{array}$ & - & $\begin{array}{l}324.0 \\
(60.0 \%)\end{array}$ & $\begin{array}{l}27.0 \\
(5.0 \%)\end{array}$ & $D, C$ & PPT $\left(++^{*}\right), C$ & $\begin{array}{l}262.2 \pm 5.6 \\
(0.122 \pm 0.036)\end{array}$ & $\begin{array}{l}213.0 \pm 3.2 \\
(0.120 \pm 0.027)\end{array}$ & $\begin{array}{l}173.2 \pm 1.9 \\
(0.126 \pm 0.027)\end{array}$ \\
\hline B3 & $\begin{array}{l}135.0 \\
(26.3 \%)\end{array}$ & - & $\begin{array}{l}324.0 \\
(63.2 \%)\end{array}$ & $\begin{array}{l}0.0 \\
(0.0 \%)\end{array}$ & $\mathrm{D}, \mathrm{C}$ & PPT $(++), C$ & $\begin{array}{l}264.6 \pm 2.7 \\
(0.134 \pm 0.032)\end{array}$ & $\begin{array}{l}226.9 \pm 2.0 \\
(0.084 \pm 0.03 \mathrm{I})\end{array}$ & $\begin{array}{l}168.9 \pm 4.1 \\
(0.136 \pm 0.036)\end{array}$ \\
\hline $\mathrm{Cl}$ & $\begin{array}{l}84.6 \\
(14.9 \%)\end{array}$ & $\begin{array}{l}338.6 \\
(59.7 \%)\end{array}$ & - & $\begin{array}{l}89.8 \\
(15.8 \%)\end{array}$ & PPT $(++++), C$ & PPT $(+++++), C$ & - & - & - \\
\hline C2 & $\begin{array}{l}85.1 \\
(15.8 \%)\end{array}$ & $\begin{array}{l}340.2 \\
(63.0 \%)\end{array}$ & - & $\begin{array}{l}60.8 \\
(11.3 \%)\end{array}$ & $\operatorname{PPT}(++++), \mathrm{C}$ & $\mathrm{PPT}(+++++), \mathrm{C}$ & - & - & - \\
\hline C3 & $\begin{array}{l}84.9 \\
(16.6 \%)\end{array}$ & $\begin{array}{l}339.7 \\
(66.2 \%)\end{array}$ & - & $\begin{array}{l}34.4 \\
(6.7 \%)\end{array}$ & PPT $(++), C$ & $\operatorname{PPT}(+++), C$ & - & - & - \\
\hline DI & $\begin{array}{l}84.6 \\
(14.9 \%)\end{array}$ & - & $\begin{array}{l}338.6 \\
(59.7 \%)\end{array}$ & $\begin{array}{l}89.8 \\
(15.8 \%)\end{array}$ & PPT $(+++), C l$ & PPT $(++++), C l$ & - & - & - \\
\hline D2 & $\begin{array}{l}85.1 \\
(15.8 \%)\end{array}$ & - & $\begin{array}{l}340.2 \\
(63.0 \%)\end{array}$ & $\begin{array}{l}60.8 \\
(11.3 \%)\end{array}$ & PPT $(+++), \mathrm{Cl}$ & PPT $(++++), C l$ & - & - & - \\
\hline D3 & $\begin{array}{l}84.9 \\
(16.6 \%)\end{array}$ & - & $\begin{array}{l}339.7 \\
(66.2 \%)\end{array}$ & $\begin{array}{l}34.4 \\
(6.7 \%)\end{array}$ & $\operatorname{PPT}(++), C$ & PPT $(+++), C$ & - & - & - \\
\hline EI & $\begin{array}{l}41.0 \\
(7.2 \%)\end{array}$ & $\begin{array}{l}369.4 \\
(65.1 \%)\end{array}$ & - & $\begin{array}{l}102.6 \\
(18.1 \%)\end{array}$ & PPT(++++), C & PPT $(+++++), C$ & - & - & - \\
\hline E2 & $\begin{array}{l}41.3 \\
(7.7 \%)\end{array}$ & $\begin{array}{l}371.8 \\
(68.9 \%)\end{array}$ & - & $\begin{array}{l}72.9 \\
(13.5 \%)\end{array}$ & PPT $(++++), C$ & PPT(+++++), C & - & - & - \\
\hline E3 & $\begin{array}{l}41.3 \\
(8.1 \%)\end{array}$ & $\begin{array}{l}371.8 \\
(72.5 \%)\end{array}$ & - & $\begin{array}{l}45.9 \\
(8.9 \%)\end{array}$ & PPT $(+++), C$ & $\mathrm{PPT}(++++), \mathrm{C}$ & - & - & - \\
\hline $\mathrm{FI}$ & $\begin{array}{l}41.0 \\
(7.2 \%)\end{array}$ & - & $\begin{array}{l}369.4 \\
(65.1 \%)\end{array}$ & $\begin{array}{l}102.6 \\
(18.1 \%)\end{array}$ & $\operatorname{PPT}(+++), S$ & PPT $(++++), S$ & - & - & - \\
\hline F2 & $\begin{array}{l}41.3 \\
(7.7 \%)\end{array}$ & - & $\begin{array}{l}371.8 \\
(68.9 \%)\end{array}$ & $\begin{array}{l}72.9 \\
(13.5 \%)\end{array}$ & PPT $(+++)$, SS & PPT $(++++)$, SS & - & - & - \\
\hline F3 & $\begin{array}{l}41.3 \\
(8.1 \%)\end{array}$ & - & $\begin{array}{l}371.8 \\
(72.5 \%)\end{array}$ & $\begin{array}{l}45.9 \\
(8.9 \%)\end{array}$ & $\mathrm{PPT}(+++), \mathrm{C}$ & $\mathrm{PPT}(+++), \mathrm{C}$ & - & - & - \\
\hline
\end{tabular}

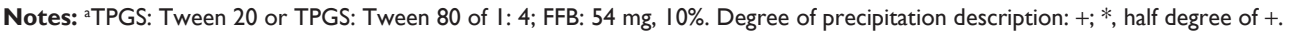
Abbreviations: D, dissolved; C, clear; Cl, cloudy; S, solid; SS, semisolid; PPT, precipitation. 
Table 2 Formulation compositions and physical characteristics (appearance, mean particle size, and polydispersity index [PI]) of fenofibrate (FFB) self-microemulsifying drug delivery system (SMEDDS) composed of D- $\alpha$-tocopheryl polyethylene glycol I 000 succinate (TPGS) as the surfactant and Tween ${ }^{\circledR} 20(\mathrm{G}, \mathrm{M}, \mathrm{O}, \mathrm{S}$, and $\mathrm{T})$ or Tween ${ }^{\circledR} 80(\mathrm{H}, \mathrm{P}, \mathrm{R}, \mathrm{U}$, and $\mathrm{V})$ as the cosurfactant at various oil/S mix ratios ( $\mathrm{G}$ and $\mathrm{H}$ at I.38, $\mathrm{M}$ and $\mathrm{P}$ at I.II, $\mathrm{S}$ and $\mathrm{U}$ at $0.9, \mathrm{~T}$ and $\mathrm{V}$ at 0.58 , and $\mathrm{O}$ and $\mathrm{R}$ at 0.46 ) and the same water content (4.5\%)

\begin{tabular}{|c|c|c|c|c|c|c|c|c|c|}
\hline \multirow[t]{2}{*}{ Code } & \multirow{2}{*}{$\begin{array}{l}\text { Myritol }^{\circledR} \\
318(\mathrm{mg}, \%)\end{array}$} & \multirow{2}{*}{$\begin{array}{l}\text { TPGS/ } \\
\text { Tween } 20 \\
(\mathrm{mg}, \%)^{\mathrm{a}}\end{array}$} & \multirow{2}{*}{$\begin{array}{l}\text { TPGS/ } \\
\text { Tween } 80 \\
(\mathrm{mg}, \%)^{\mathrm{a}}\end{array}$} & \multirow[t]{2}{*}{ Oil/s $\mathbf{S}_{\text {mix }}$} & \multicolumn{2}{|l|}{ Appearance } & \multicolumn{3}{|c|}{ Particle size (PI) } \\
\hline & & & & & (12 hours) ${ }^{b}$ & $(\text { I week) })^{b}$ & $10 \mathrm{rpm}$ & $25 \mathrm{rpm}$ & $50 \mathrm{rpm}$ \\
\hline G & $\begin{array}{l}267.3 \\
(49.5 \%)\end{array}$ & $\begin{array}{l}194.4 \\
(36.0 \%)\end{array}$ & - & 1.38 & $\mathrm{D}, \mathrm{S}$ & $\begin{array}{l}\text { PPT }(*), \\
\text { SE }(+++++)\end{array}$ & - & - & - \\
\hline$M$ & $\begin{array}{l}243.0 \\
(45.0 \%)\end{array}$ & $\begin{array}{l}218.7 \\
(40.5 \%)\end{array}$ & - & 1.11 & $D, S$ & $D, S E(++++)$ & - & - & - \\
\hline S & $\begin{array}{l}218.7 \\
(40.5 \%)\end{array}$ & $\begin{array}{l}243.0 \\
(45.0 \%)\end{array}$ & - & 0.90 & $D, S$ & $\begin{array}{l}\mathrm{PPT}(+), \\
\mathrm{SS}(+++)\end{array}$ & $\begin{array}{l}381.1 \pm 14.9 \\
(0.236 \pm 0.04 I)\end{array}$ & $\begin{array}{l}347.9 \pm 8.2 \\
(0.242 \pm 0.020)\end{array}$ & $\begin{array}{l}313.8 \pm 9.3 \\
(0.198 \pm 0.032)\end{array}$ \\
\hline $\mathrm{N}$ & $\begin{array}{l}194.4 \\
(36.0 \%)\end{array}$ & $\begin{array}{l}267.3 \\
(49.5 \%)\end{array}$ & - & 0.73 & $D, C$ & $\begin{array}{l}\mathrm{PPT}\left(+^{*}\right), \\
\mathrm{SE}\left({ }^{*}\right)\end{array}$ & $\begin{array}{l}407.2 \pm 10.4 \\
(0.260 \pm 0.020)\end{array}$ & $\begin{array}{l}402.8 \pm 12.1 \\
(0.230 \pm 0.029)\end{array}$ & $\begin{array}{l}379.2 \pm 13.1 \\
(0.167 \pm 0.04 I)\end{array}$ \\
\hline $\mathrm{T}$ & $\begin{array}{l}170.1 \\
(31.5 \%)\end{array}$ & $\begin{array}{l}291.6 \\
(54.0 \%)\end{array}$ & - & 0.58 & $D, C$ & $\mathrm{D}, \mathrm{C}$ & $\begin{array}{l}416.7 \pm 15.2 \\
(0.194 \pm 0.047)\end{array}$ & $\begin{array}{l}347.0 \pm 7.3 \\
(0.144 \pm 0.048)\end{array}$ & $\begin{array}{l}293.0 \pm 15.1 \\
(0.143 \pm 0.032)\end{array}$ \\
\hline O & $\begin{array}{l}145.8 \\
(27.0 \%)\end{array}$ & $\begin{array}{l}315.9 \\
(58.5 \%)\end{array}$ & - & 0.46 & $\mathrm{D}, \mathrm{C}$ & PPT(++), C & $\begin{array}{l}368.3 \pm 12.9 \\
(0.177 \pm 0.025)\end{array}$ & $\begin{array}{l}323.8 \pm 8.7 \\
(0.177 \pm 0.029)\end{array}$ & $\begin{array}{l}279.2 \pm 4.5 \\
(0.177 \pm 0.033)\end{array}$ \\
\hline $\mathrm{H}$ & $\begin{array}{l}267.3 \\
(49.5 \%)\end{array}$ & - & $\begin{array}{l}194.4 \\
(36.0 \%)\end{array}$ & 1.38 & $\mathrm{D}, \mathrm{C}$ & $\operatorname{PPT}(+), C$ & - & - & - \\
\hline$P$ & $\begin{array}{l}243.0 \\
(45.0 \%)\end{array}$ & - & $\begin{array}{l}218.7 \\
(40.5 \%)\end{array}$ & 1.11 & $\mathrm{D}, \mathrm{C}$ & $\operatorname{PPT}(+), C$ & - & - & - \\
\hline U & $\begin{array}{l}218.7 \\
(40.5 \%)\end{array}$ & - & $\begin{array}{l}243.0 \\
(45.0 \%)\end{array}$ & 0.90 & $D, C$ & $\operatorname{PPT}(+), C$ & $\begin{array}{l}397.2 \pm 30.1 \\
(0.059 \pm 0.030)\end{array}$ & $\begin{array}{l}350.7 \pm 14.5 \\
(0.101 \pm 0.043)\end{array}$ & $\begin{array}{l}353.9 \pm 17.1 \\
(0.129 \pm 0.042)\end{array}$ \\
\hline Q & $\begin{array}{l}194.4 \\
(36.0 \%)\end{array}$ & - & $\begin{array}{l}267.3 \\
(49.5 \%)\end{array}$ & 0.73 & $\mathrm{D}, \mathrm{C}$ & PPT(++), C & $\begin{array}{l}487.5 \pm 19.5 \\
(0.114 \pm 0.049)\end{array}$ & $\begin{array}{l}354.2 \pm 14.0 \\
(0.185 \pm 0.046)\end{array}$ & $\begin{array}{l}280.1 \pm 5.3 \\
(0.193 \pm 0.031)\end{array}$ \\
\hline v & $\begin{array}{l}170.1 \\
(31.5 \%)\end{array}$ & - & $\begin{array}{l}291.6 \\
(54.0 \%)\end{array}$ & 0.58 & $D, C$ & $D, C$ & $\begin{array}{l}418.2 \pm 9.0 \\
(0.131 \pm 0.038)\end{array}$ & $\begin{array}{l}267.6 \pm 5.8 \\
(0.201 \pm 0.021)\end{array}$ & $\begin{array}{l}223.1 \pm 2.8 \\
(0.161 \pm 0.026)\end{array}$ \\
\hline$R$ & $\begin{array}{l}145.8 \\
(27.0 \%)\end{array}$ & - & $\begin{array}{l}315.9 \\
(58.5 \%)\end{array}$ & 0.46 & $\mathrm{D}, \mathrm{C}$ & PPT $(++), C$ & $\begin{array}{l}285.4 \pm 7.8 \\
(0.115 \pm 0.036)\end{array}$ & $\begin{array}{l}221.9 \pm 5.6 \\
(0.098 \pm 0.025)\end{array}$ & $\begin{array}{l}204.5 \pm 2.1 \\
(0.156 \pm 0.033)\end{array}$ \\
\hline
\end{tabular}

Notes: ${ }^{\text {TTPGS: Tween }} 20$ or TPGS: Tween 80 of I: 4; FFB: 54 mg, 10\%; $\mathrm{H}_{2} \mathrm{O}: 24.3 \mathrm{mg}, 4.5 \%$; total weight: 540 mg. Degree of precipitation description: +; *, half degree of +. Abbreviations: D, dissolved; C, clear; SE, separated; SS, semisolid; PPT, precipitation.

to a weight of about $540 \mathrm{mg}$. The capsules were kept at ambient temperature.

\section{Dissolution studies and particle characterization}

The dissolution profiles of the FFB SMEDDS capsules were determined using the USP 25 dissolution apparatus II (VK7020S; Varian Inc, Palo Alto, CA) method. The dissolution media consisted of $500 \mathrm{~mL}$ of simulated gastric fluid ( $\mathrm{pH}$ 1.2). The temperature of the medium was maintained at $37.0^{\circ} \mathrm{C} \pm 0.5^{\circ} \mathrm{C}$, and the rotation speed was set to three different speeds of 10,25 , and $50 \mathrm{rpm}$, since rotation speeds of 75 and $100 \mathrm{rpm}$ were found to result in an insignificant difference in the release rate. Samples $(5 \mathrm{~mL})$ were automatically withdrawn at $0,5,10,20,30,60,90,120,180$, and 270 minutes and fresh medium replaced. The sample was then diluted with a threefold volume of absolute alcohol to achieve an appropriate linear concentration range and prevent the drug from precipitating. Samples were then measured spectrophotometrically at $287 \mathrm{~nm}$ (using a Jasco V-550 UV/VIS spectrophotometer; JASCO International Co, Ltd, Tokyo, Japan) to determine the amount of drug released. The average percentage drug dissolved at each sampling time $(\mathrm{n}=3$ ) was calculated after correcting for the cumulative amount removed in previous samples. The UV method for quantification of FFB was validated to ensure acceptable precision and accuracy for intra- and interday measurements (data not shown).

The mean particle size and polydispersity index of FFB particles in the portion of each sample were determined using a nanoparticle size analyzer (BIC 90 PLUS; Brookhaven Instruments, Holtsville, NY). Before the measurement, samples were diluted with double-distilled water to a suitable scattering intensity. Processing the fluctuating signal with a digital autocorrelator yielded the particle's diffusion coefficient, from which the equivalent spherical particle size was calculated using the StokesEinstein equation. 


\section{Pharmacokinetic studies}

Healthy volunteers were recruited after signing an informed consent agreement approved by the Ethics Committee of Taipei Medical University Hospital. A parallel design was conducted with four subjects for each treatment of three formulations (SMEDDS B2 and Q, and a B2 solution) at the same strength $(54 \mathrm{mg})$. After dosing, blood samples $(10 \mathrm{~mL})$ were collected in BD Vacutainers ${ }^{\mathrm{TM}}$ (Becton, Dickinson and Company, Franklin Lakes, NJ) containing $\mathrm{K}_{3}$ EDTA by means of an indwelling venous cannula in the cubital vein according to a predetermined time schedule, which included a blank sample, just before dosing and then samples at $0.5,1,2,3,4,5,6,7,8,10,12,24,36$, and 60 hours after dosing. Plasma was immediately separated by centrifugation at $1690 \mathrm{~g}$ for 10 minutes, then transferred to suitably labeled tubes, and stored at $-80^{\circ} \mathrm{C}$ until analysis. The plasma drug concentration was assayed with the validated high-performance liquid chromatographic (HPLC) method described below.

The HPLC system consisted of an Intelligent HPLC pump (PU-980; JASCO), an autosampler (AS-1555-10; JASCO), an UV/VIS detector (UV-975; JASCO), and a column oven $\left(40^{\circ} \mathrm{C}\right.$ ). A column of Gemini ${ }^{\circledR} \mathrm{C}_{18} 110 \mathrm{~A}$ (Phenomenex, Inc, Torrance, CA) $(5 \mu \mathrm{m}, 150 \times 4.6 \mathrm{~mm})$ was employed with a mobile phase consisting of acetonitrile: $\mathrm{H}_{2} \mathrm{O}$ acetic acid of 55:45:0.2 (v/v, \%) at a flow rate of $1 \mathrm{~mL} /$ minute. The eluent was monitored with a UV detector at a wavelength of $287 \mathrm{~nm}$. Ketoprofen $(40 \mu \mathrm{g} / \mathrm{mL})$ was used as the internal standard. FBA, a major in vivo metabolite of FFB and used as a standard, was prepared with the solvent mixture of acetonitrile: $\mathrm{H}_{2} \mathrm{O}$ of $4: 1$ in the concentration range of $0.1,0.2,0.5,1.0,2.0$, and $5.0 \mu \mathrm{g} / \mathrm{mL}$, and three quality control (QC) samples of $0.3,2.5$, and $4.0 \mu \mathrm{g} / \mathrm{mL}$ were dispensed in the same solvent mixture. Standard curves were constructed by adding $50 \mu \mathrm{L}$ each of freshly prepared standard solutions and the internal standard stock solution to $0.5 \mathrm{~mL}$ of plasma in a $10 \mathrm{~mL}$ screw-top test tube. Plasma samples were then deproteinated by adding $0.1 \mathrm{~mL}$ of acetonitrile:70\% perchloric acid at 1:1 and briefly vortexed for 1 minute. The sample mixtures were centrifuged at $1690 \mathrm{~g}$ for 10 minutes at $4^{\circ} \mathrm{C}$. The supernatant aqueous layer was pipetted out, and $400 \mu \mathrm{L}$ was injected into a column for the HPLC analysis. Based on plasma profiles, all parameters of the pharmacokinetic study as defined were calculated using noncompartmental models for the period of 0-60 hours. The maximum concentrations $\left(\mathrm{C}_{\max }\right)$ and the time to reach $\mathrm{C}_{\max }\left(\mathrm{T}_{\max }\right)$ were determined from the respective observed plasma concentrations versus time data. The elimination rate constant $\left(k_{\mathrm{e}}\right)$ was obtained by linear regression analysis of at least three sampling points of the terminal log-linear declining phase to the last measurable concentration. The elimination half-life $\left(T_{1 / 2}\right)$ was calculated as $\ln 2 / k_{\mathrm{e}}$. The area under the curve (AUC) to the last measurable concentration $\left(\mathrm{AUC}_{0 \text {-last }}\right)$ was calculated by the linear trapezoidal rule. The apparent oral clearance $(C l)$ was calculated as Dose $/ \mathrm{AUC}_{0 \text {-inf }}$ and the mean residence time was calculated as $\mathrm{AUMC}_{0 \text {-inf }} / \mathrm{AUC}_{0 \text {-inf }}$. The relative bioavailability $(F \%)$ was calculated as $\mathrm{AUC}_{0-60 \text {,sample }} / \mathrm{AUC}_{0-60, \text { Tricor }} \times 100$. Results of inter- and intraday validations indicated that the correlation coefficients were all $>0.999$, and the variabilities of the slopes and intercepts were all $<5 \%$ for all calibration curves constructed from the inter- and intraday assays. The relative standard error (RSE\%) and coefficient of variation (CV\%) were better than $20 \%$ at the lower limit of quantification ( 0.1 $\mu \mathrm{g} / \mathrm{mL}$ ) and better than $15 \%$ at the remaining concentrations in both the intra- and interday analyses.

\section{Statistical analysis}

All results are presented as the mean \pm standard deviation (SD). A one-way analysis of variance (ANOVA) was used to determine statistical significance of particle size, time when $50 \%$ drug released, and pharmacokinetic parameters between groups (PASW Statistics 18.0; IBM Corp, Armonk, NY), and $P<0.05$ was considered to be statistically significant.

\section{Results and discussion Physical characterizations of the SMEDDS formulations}

The solubility of FFB is known to vary with those components employed to formulate SMEDDSs examined in this study. It has been reported that $1 \mathrm{~g}$ of Myritol 318 could dissolve $94.14 \pm 3.15 \mathrm{mg} / \mathrm{g}$ of FFB. The solubilities of FFB in $10 \%$ TPGS, $10 \%$ Tween 20 , and $10 \%$ Tween 80 solutions were $1.56 \pm 0.08,0.52 \pm 0.01$, and $0.80 \pm 0.02 \mathrm{mg} / \mathrm{g}$, respectively. ${ }^{36}$ Thus, the physical characteristics, including the appearance and solution status, of the SMEDDS formulations composed of Myritol 318 as the oil phase and TPGS/Tween 20 or 80 as the surfactant/cosurfactant at the same level of $10 \% \mathrm{FFB}$ based on the pseudoternary phase diagrams as reported previously ${ }^{14}$ were examined to select those SMEDDSs with optimal solubility for further evaluation. The detailed compositions of the two groups (Group I with various lower levels of oil $/ \mathrm{S}_{\text {mix }}$ ratios: $\mathrm{A}$ and $\mathrm{B}$ of $0.42, \mathrm{C}$ and $\mathrm{D}$ of 0.25 , and $\mathrm{E}$ and $\mathrm{F}$ of 0.11 and water contents: $0.0 \%, 5.0 \%$, and 9.5\%; Group II with various higher levels of oil $/ \mathrm{S}_{\text {mix }}$ ratios: $\mathrm{G}$ and $\mathrm{H}$ of $1.38, \mathrm{M}$ and $\mathrm{P}$ of $1.11, \mathrm{~S}$ and $\mathrm{U}$ of $0.9, \mathrm{~T}$ and $\mathrm{V}$ of 0.58 , and $\mathrm{O}$ and $\mathrm{R}$ of 0.46 and the same water content of 
$4.5 \%$ ) of SMEDDS formulations containing either TPGS/ Tween 20 or 80 are listed in Tables 1 and 2, respectively. For Group I (formulations A-F), it was found that only the $A$ and $B$ series of SMEDDS formulations maintained a dissolved status with no precipitation of FFB at 12 hours after preparation. Whereas, 1 week after preparation, FFB was observed to have precipitated out to a small extent in both $\mathrm{A}$ and $B$ series of SMEDDS formulations but at a higher extent from the other formulations $(\mathrm{C}-\mathrm{F})$ in this group. For Group II with a higher oil/ $\mathrm{S}_{\text {mix }}$ ratio (formulations $\mathrm{G}-\mathrm{O}$ containing Tween 20 and formulations H-R containing Tween 80), FFB was completely dissolved in SMEDDS formulations using either Tween 20 or 80 as the cosurfactant at all oil $/ \mathrm{S}_{\text {mix }}$ ratios 12 hours after preparation, but phase separation was only observed for those SMEDDS formulations containing the Tween 20 at the higher oil $/ \mathrm{S}_{\text {mix }}$ ratio (formulations $\mathrm{G}, \mathrm{M}$, and S). At 1 week after preparation, FFB was found to have precipitated from all SMEDDS formulations containing either Tween 20 or 80 , with the former showing a greater level of precipitation than the latter, except the SMEDDS formulations of T (containing Tween 20) and V (containing Tween 80 ) at an oil $/ \mathrm{S}_{\text {mix }}$ ratio of 0.58 , which maintained complete dissolution with no phase separation.

\section{In vitro dissolution characterizations}

Those SMEDDS formulations selected above were further subjected to dissolution studies excluding formulations C, D, $\mathrm{E}$, and $\mathrm{F}$ in Group I, for which severe FFB precipitation was observed 1 week after preparation, and formulations $\mathrm{G}, \mathrm{M}, \mathrm{H}$, and $\mathrm{P}$ in Group II. For the first two, Tween 20 as the cosurfactant was insufficient for a higher level of oil content to be microemulsified into a single phase, and Tween 80 was the cosurfactant at the same oil/ $\mathrm{S}_{\text {mix }}$ ratio as formulations $\mathrm{G}$ and $\mathrm{M}$ in the latter two.

\section{Particle size characterizations}

The results of mean particle size versus time profiles at three stirring rates are illustrated in Figures 1 and 2, respectively, for Group I (series A and B) and II (Tween 20 series: N, O, S, and T; Tween 80 series: Q, R, U, and V) SMEDDS formulations. The corresponding mean size and their size distributions expressed by the polydispersity index for the last time point of the dissolution study are listed in Table 1. Comparing series A and B SMEDDS formulations at three stirring rates (Figure 1) showed that FFB drug particles formed within the nanosize range gradually increased with time but decreased with an increase in the stirring rate at the same time point for both series. A minor difference was shown in the size of the
FFB drug particles formed by these SMEDDS formulations containing various water contents within the same series. However, the mean particle size of FFB formed by the series B was as small as $200 \mathrm{~nm}$, which was smaller than the corresponding SMEDDS formulations of series $A$ at all three stirring rates. Similar results were observed for the particle characteristics determined for the final sampling time point, as shown in Table 1. It was concluded that for those formulations within the SMEDDS region, Tween 80 was better than Tween 20 for precipitating FFB in SMEDDS formulations to form drug particles in a smaller size range. This effect was dependent on the stirring rate but independent of the water content. Because the hydrophilic-lipophilic balance value of Tween 80 (15) was lower than that of Tween 20 (16.7), it was expected that Tween 80 would have a higher capacity to solubilize FFB than Tween 20 resulting in the precipitation of FFB in a smaller nanosize range than those SMEDDSs containing Tween 80 as the cosurfactant.

Comparing the Tween 20 (N, O, S, and T) and Tween 80 series $(\mathrm{Q}, \mathrm{R}, \mathrm{U}$, and V) of SMEDDS formulations in Group II at three stirring rates (Figure 2) also demonstrated that FFB drug particles formed within a similar nano-size range gradually increased with time except for the $\mathrm{N}$ formulation at the two higher stirring rates, but decreased with increasing stirring rates at the same time point for both series. A decrease was shown in the mean particle size of FFB particles formed from those SMEDDS formulations with a decreasing oil $/ \mathrm{S}_{\text {mix }}$ ratio within the same series except for formulation $\mathrm{S}$ in the Tween 20 series at all three stirring rates, and formulation $U$ in the Tween 80 series at the lowest stirring rate of $10 \mathrm{rpm}$. However, the mean particle size of FFB formed by the Tween 80 series reached the $200 \sim 300 \mathrm{~nm}$ range at the highest stirring rate of $50 \mathrm{rpm}$, which was smaller than the corresponding SMEDDS formulations of the Tween 20 series at the same stirring rate except for formulation Q in the Tween 80 series at the lowest stirring rate of $10 \mathrm{rpm}$. Similar results were observed for the particle characteristics determined for the final sampling time point as demonstrated in Table 2. Because formulation $\mathrm{S}$ of the Tween 20 series was unable to form a SMEDDS leading to phase separation as demonstrated in Table 2, the portion of FFB which dissolved in the oil phase separated from the SMEDDS during dissolution, causing a smaller amount of FFB to be precipitated and form drug particles with a smaller mean size than for the other formulations of the Tween 20 series. On the other hand, a larger mean size of FFB particles formed from formulation $\mathrm{Q}$ at the lowest stirring rate of $10 \mathrm{rpm}$ could be attributed to the higher viscosity of Tween 80 at a higher $\mathrm{oil} / \mathrm{S}_{\text {mix }}$ ratio of 0.73 , which increased the droplet size of the 

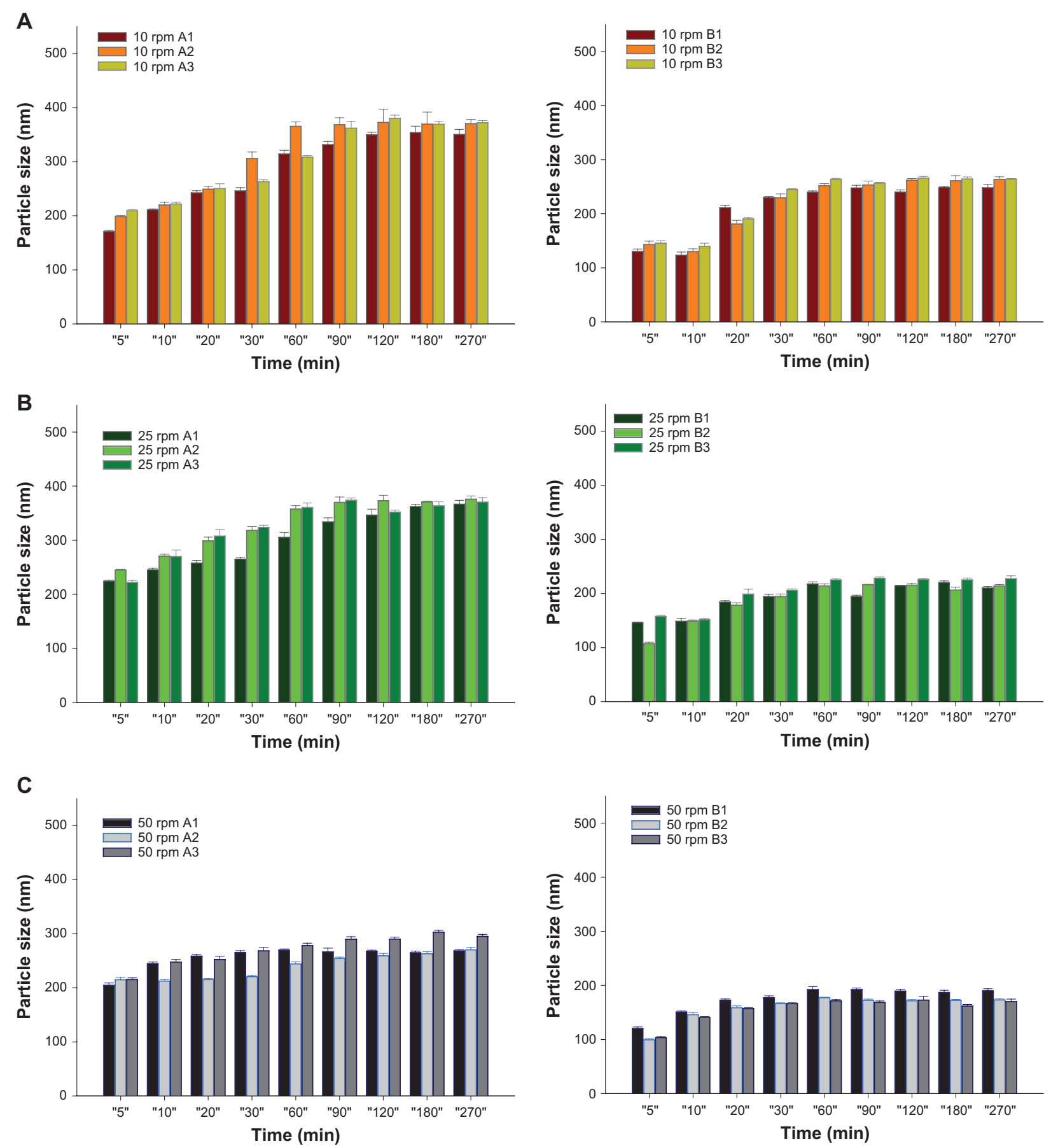

Figure I Dissolution profiles of fenofibrate (FFB) from self-microemulsifying drug delivery system (SMEDDS) formulations composed of D- $\alpha$-tocopheryl polyethylene glycol 1000 succinate (TPGS) as the surfactant and Tween 20 (AI, A2, and A3) or Tween 80 (BI, B2, and B3) as the cosurfactant at various stirring rates: (A) I0 rpm, (B) 25 rpm, (C) $50 \mathrm{rpm}$.

microemulsified internal phase. Rationally, this viscosity effect on the formation of droplet size of the internal phase was only significant at a lower stirring rate $(P<0.001)$.

\section{Dissolution profile characterizations}

The drug released (\%) from those SMEDDS formulations in the dissolution study was measured after dilution by the addition of absolute alcohol to dissolve those FFB nanoparticles in the dissolution medium to an appropriate concentration range. Figures 3 and 4, respectively, illustrate the release profiles for Groups I (series A and B) and II (Tween 20 series: N, O, S, and T; and Tween 80 series: Q, $\mathrm{R}, \mathrm{U}$, and $\mathrm{V}$ ) at three stirring rates. As shown in Figure 3, the release rates from both series A and B SMEDDSs obviously 

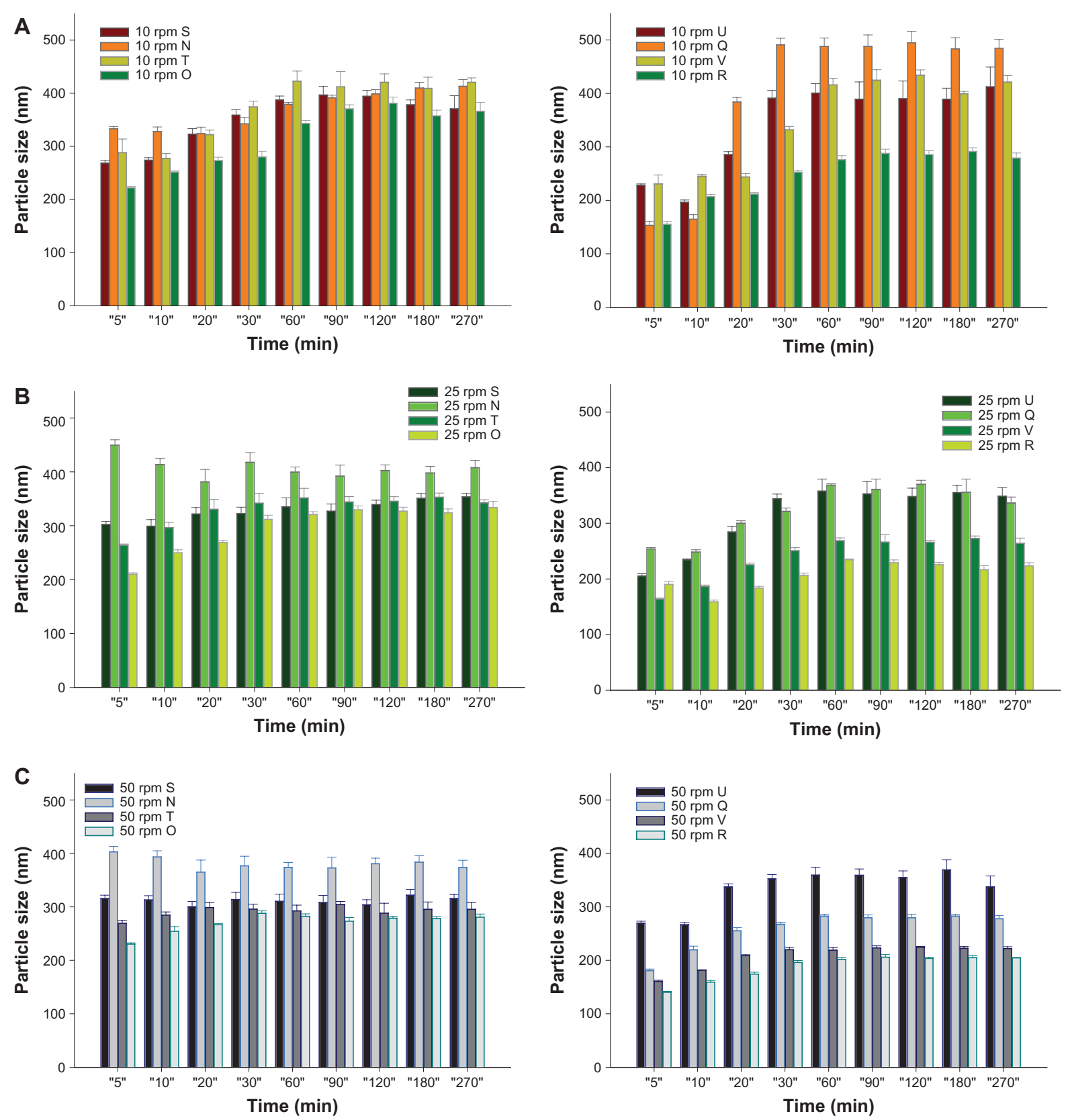

Figure 2 Dissolution profiles of fenofibrate (FFB) from self-microemulsifying drug delivery system (SMEDDS) formulations composed of D- $\alpha$-tocopheryl polyethylene glycol 1000 succinate (TPGS) as the surfactant and Tween ${ }^{\circledR} 20(\mathrm{~N}, \mathrm{O}, \mathrm{S}$, and $\mathrm{T})$ or Tween ${ }^{\circledR} 80(\mathrm{Q}, \mathrm{R}, \mathrm{U}$, and $\mathrm{V})$ as the cosurfactant at various oil/S mix ratios $(\mathrm{S}$ and $\mathrm{U}$ at $0.9, \mathrm{~N}$ and $Q$ at $0.73, T$ and $V$ at 0.58 , and $O$ and $R$ at 0.46$)$ with the same water content (4.5\%) at various stirring rates: (A) $10 \mathrm{rpm},(\mathbf{B}) 25 \mathrm{rpm},(\mathbf{C}) 50 \mathrm{rpm}$.

increased with an increasing stirring rate $(P<0.001$ for series A and $P=0.003$ for series $\mathrm{B})$. At the lower stirring rate of $10 \mathrm{rpm}$ (Figure $3 \mathrm{~A}$ ), the release rate from series $\mathrm{A}$ seemed to decrease with an increasing water content (A1 $[9.5 \%]<\mathrm{A} 2[5.0 \%]<\mathrm{A} 3[0.0 \%])$, whereas that from series $\mathrm{B}$ followed an opposite trend $(\mathrm{B} 1[9.5 \%] \cong \mathrm{B} 2[5.0 \%]>\mathrm{B} 3$ $[0.0 \%])$. Further, only the release rate from series $\mathrm{B}$ containing $0 \%$ water content (B3) was slower than that from the corresponding series A containing the same water content. With an increase in the stirring rate to $25 \mathrm{rpm}$ (Figure 3B), no difference was evident among the release rates from series B $(P=0.896)$, and all were faster than those from the corresponding series A formulations with the same water content. The release rate from $\mathrm{A} 3$ was a little faster than those from $\mathrm{A} 1$ and $\mathrm{A} 2$. With a further increase in the stirring rate to $50 \mathrm{rpm}$ (Figure $3 \mathrm{C}$ ), the release rates from series A were in the order of $\mathrm{A} 1 \cong \mathrm{A} 2>\mathrm{A} 3$, whereas those from series $\mathrm{B}$ were in the order of $\mathrm{B} 3>\mathrm{B} 2 \cong \mathrm{B} 1$, all of which were slower than those from the corresponding series A containing the same water content. 

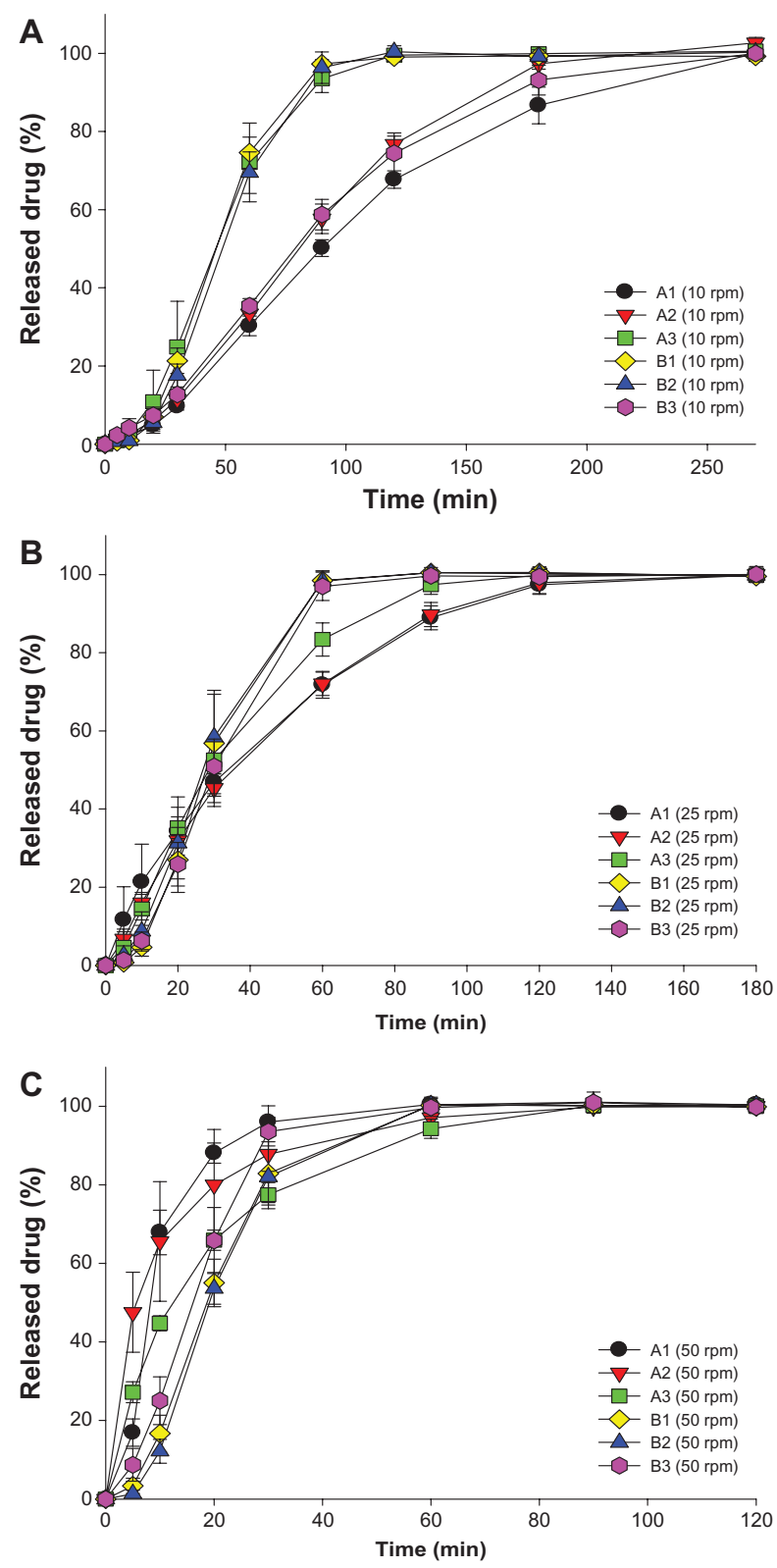

Figure 3 Mean particle size profiles of fenofibrate (FFB) from self-microemulsifying drug delivery system (SMEDDS) formulations composed of $D$ - $\alpha$-tocopheryl polyethylene glycol 1000 succinate (TPGS) as the surfactant and Tween ${ }^{\circledR} 20$ (AI, A2, and A3) or Tween ${ }^{\circledR} 80(\mathrm{BI}, \mathrm{B} 2$, and $\mathrm{B} 3)$ as the cosurfactant at various stirring rates: (A) $10 \mathrm{rpm},(B) 25 \mathrm{rpm}$, (C) $50 \mathrm{rpm}$.

Similarly, as shown in Figure 4, the release rates from both Tween 20 series $(\mathrm{N}, \mathrm{O}, \mathrm{S}$, and $\mathrm{T})$ and Tween 80 series $(\mathrm{Q}, \mathrm{R}$, $\mathrm{U}$, and $\mathrm{V}$ ) of SMEDDSs increased with an increasing stirring rate. Among the Tween 20 series, incomplete release was observed only for the S and N SMEDDSs at all three stirring rates. As described above, this was attributed to a failure of the $\mathrm{S}$ and $\mathrm{N}$ formulations to microemulsify all of the oil phase in which most of the FFB was dissolved. However, a faster release rate and complete release were observed for the Tween 80 series of SMEDDSs compared with the Tween 20 series, but no significant difference was shown among the release rates for the Tween 80 series examined $(P=0.758)$. Before the drug concentration was measured, the sampled dissolution medium was diluted with absolute alcohol, which possesses good solubility for FFB; thus, all drug particles existing in the dissolution medium would have been completely dissolved, meaning no differences in the amount released, even though different mean particle sizes were observed for the Tween 80 series in the respective dissolution medium. This result also implies that, at the same stirring rate, the microemulsification of those SMEDDSs of the Tween 80 series had to have reached the same extent to achieve the same amount of drug existing in the dissolution medium and for the same amount released to be measured.

\section{Pharmacokinetic studies}

Two optimal SMEDDSs were selected for the pharmacokinetic study conducted with a parallel design: one contained Tween 80 (B2[SMEDDS]) or a higher oil/ $\mathrm{S}_{\text {mix }}$ ratio (Q[SMEDDS]) at a dosing strength of $54 \mathrm{mg} F F B$ in capsule form, and the B2(solution) was prepared by dissolving B2 SMEDDS in the same volume of water $(250 \mathrm{~mL})$ as that usually taken with oral administration. The resultant plasma profiles for the three treatments (B2[SMEDDS], Q[SMEDDS], and B2[solution]) and that for Q(SMEDDS) compared with that for A2(SMEDDS) and Tricor conducted in a previous study ${ }^{36}$ are illustrated in Figure 5A and $\mathrm{B}$, respectively, and the corresponding calculated pharmacokinetic parameters are listed in Table 3. Results demonstrated that the AUC and $\mathrm{C}_{\text {max }}$ values were ranked in the order of $\mathrm{Q}(\mathrm{SMEDDS})>\mathrm{B} 2$ (solution) $>$ B2 $($ SMEDDS) and B2(solution) $>\mathrm{Q}($ SMEDDS $)>\mathrm{B} 2$ (SM EDDS), respectively, for this study, whereas overall both the $\mathrm{AUC}$ and $\mathrm{C}_{\max }$ values were ranked, respectively, in the order of $\mathrm{Q}(\mathrm{SMEDDS})>$ Tricor $\cong \mathrm{B} 2$ (solution) $>\mathrm{B} 2($ SMEDDS) $\cong \mathrm{A} 2(\mathrm{SMEDDS})$ and $\mathrm{B} 2$ (solution) $>\mathrm{Q}($ SMEDDS $)>$ Tricor $\cong \mathrm{B} 2$ (SMEDDS) $>\mathrm{A} 2$ (SMEDDS). These results indicate that the overall relative bioavailability based on either $\mathrm{AUC}_{0 \text {-last }}$ or $\mathrm{AUC}_{0 \text {-inf }}$ with respect to Tricor for Q(SMEDDS) was enhanced approximately 1.14-1.22-fold. The relative bioavailabilities of A2(SMEDDS) and B2(SMEDDS) were similar but less than that for B2(solution), which was close to that for Tricor. Furthermore, as indicated by the large $\mathrm{C}_{\max }$ value and the short $\mathrm{T}_{\max }$, the in vivo absorption rate for B2(solution) was the fastest of all, followed in order by $\mathrm{Q}($ SMEDDS $)>$ Tricor $\cong \mathrm{B} 2($ SMEDDS $)>\mathrm{A} 2$ (SMEDDS).

As indicated by the particle sizes at the three stirring rates shown in Table 1, the fastest in vivo absorption rate for 

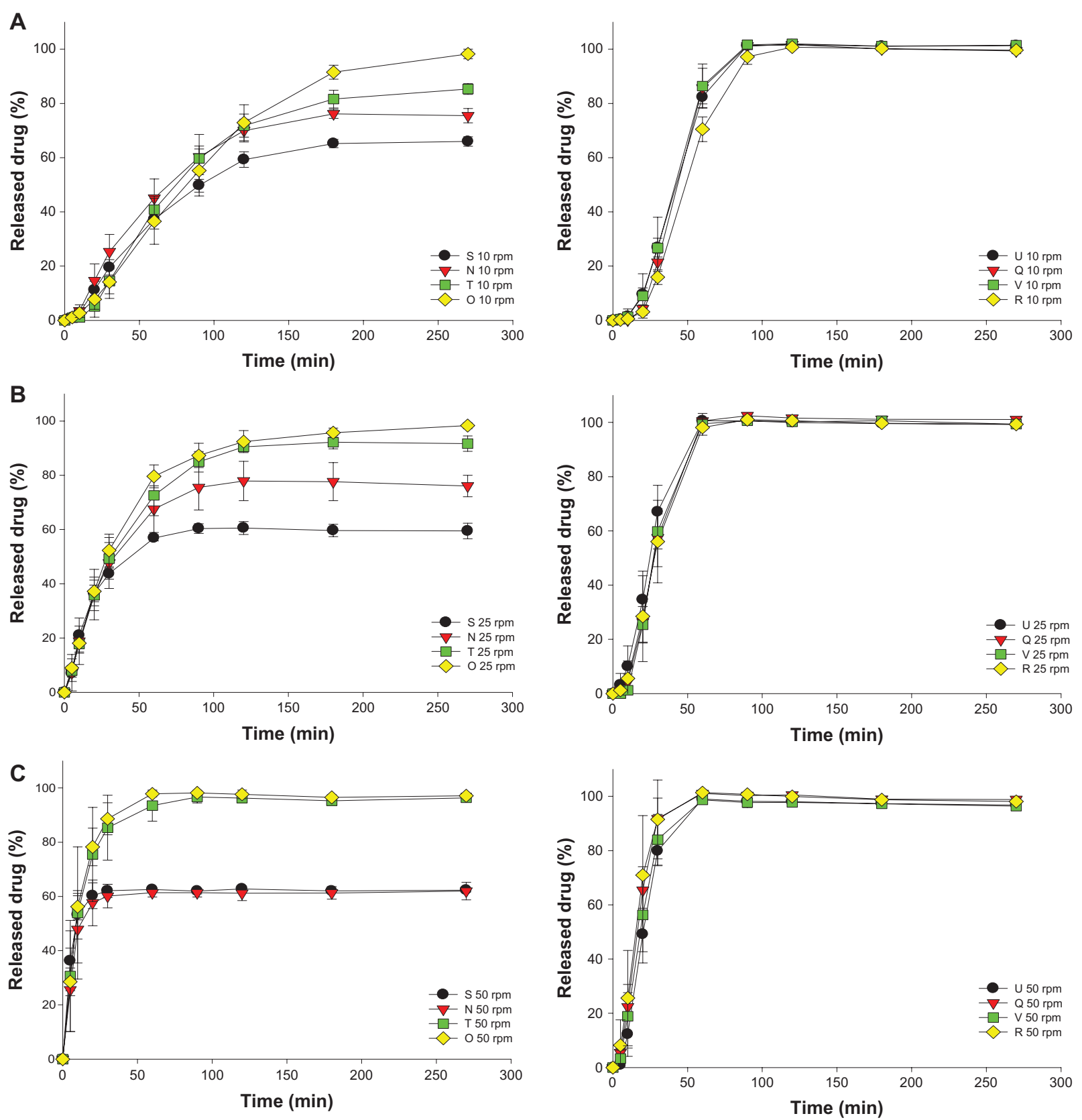

Figure 4 Mean particle size profiles of fenofibrate (FFB) from self-microemulsifying drug delivery system (SMEDDS) formulations composed of D- $\alpha$-tocopheryl polyethylene glycol 1000 succinate (TPGS) as the surfactant and Tween ${ }^{\circledR} 20(\mathrm{~N}, \mathrm{O}, \mathrm{S}$, and $\mathrm{T})$ or Tween ${ }^{\circledR} 80(\mathrm{Q}, \mathrm{R}, \mathrm{U}$, and $\mathrm{V})$ as the cosurfactant at various oil/S mix ratios $(\mathrm{S}$ and $\mathrm{U}$ of 0.9 , $\mathrm{N}$ and $\mathrm{Q}$ of $0.73, \mathrm{~T}$ and $\mathrm{V}$ of 0.58 , and $\mathrm{O}$ and $\mathrm{R}$ of 0.46$)$ with the same water content (4.5\%) at various stirring rates: (A) $10 \mathrm{rpm},(\mathbf{B}) 25 \mathrm{rpm},(\mathbf{C}) 50 \mathrm{rpm}$.

B2(solution) can potentially be attributed to the formation of a particle size in the smallest range for the B2 solution when the B2 SMEDDS was dissolved in water, making it readily available for absorption. After oral administration, the three SMEDDSs (A2, B2, and Q) would take some time for the microemulsification to dissolve before the FFB was available for absorption. Further, the mean particle size after microemulsification at the three different stirring rates for B2(SMEDDS) were all smaller than that for A2(SMEDDS).
This can be explained by the fact that the in vivo absorption rate for B2(SMEDDS) was faster than that for A2(SMEDDS). Nevertheless, this particle size effect could not be explained by the in vivo absorption rate for $\mathrm{Q}(\mathrm{SMEDDS})$ being faster than that for B2(SMEDDS). Perhaps the oil content in the higher oil $/ \mathrm{S}_{\text {mix }}$ ratio of $\mathrm{Q}(\mathrm{SMEDDS})$ played a role as a carrier providing an additional oral absorption route, such as via the lymph system, to increase the in vivo absorption rate. ${ }^{16}$ But the time required for microemulsification of 

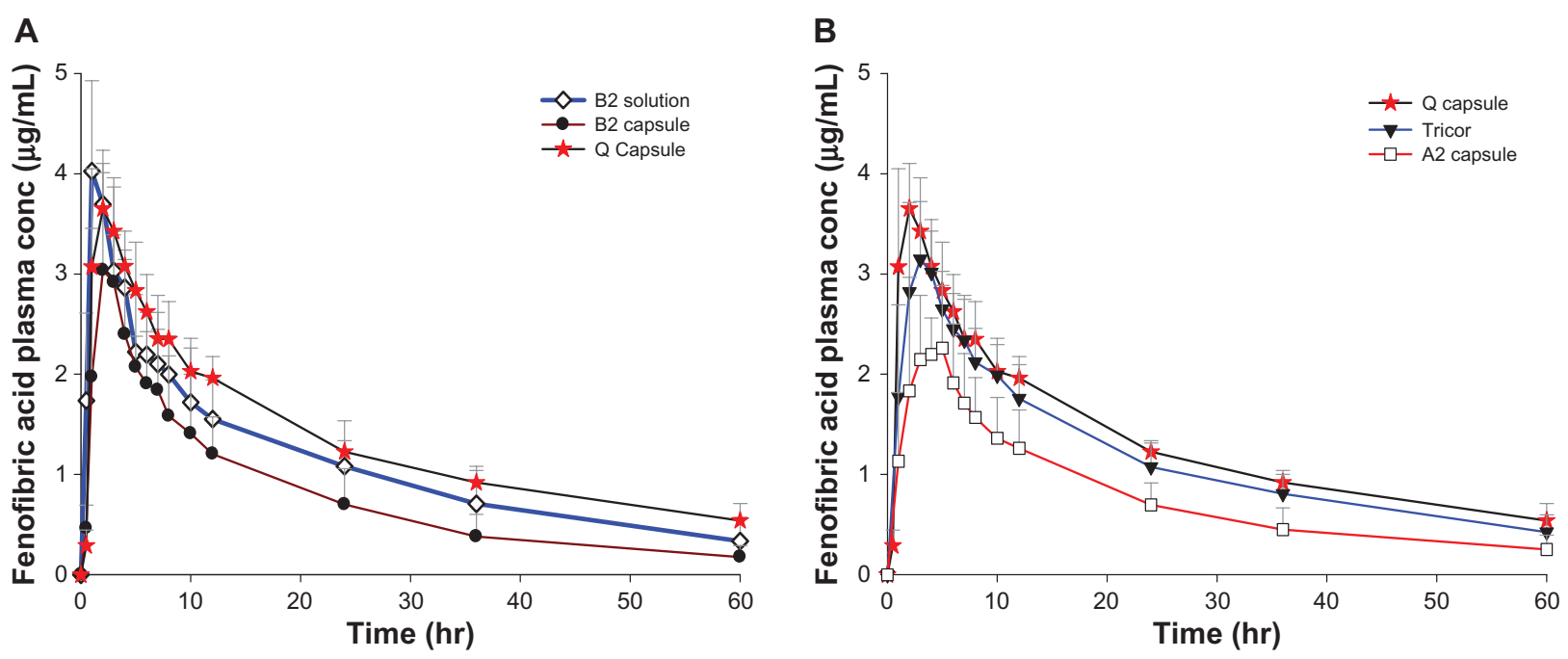

Figure 5 Plasma fenofibric acid (FBA) concentration profiles of self-microemulsifying drug delivery system (SMEDDS) formulations (all containing 54 mg fenofibrate [FFB]). (A) B2(solution), B2(SMEDDS), and Q(SMEDDS); (B) A2(SMEDDS), Q(SMEDDS), and Tricor ${ }^{\circledast}$ tablets.

$\mathrm{Q}(\mathrm{SMEDDS})$ in the gastrointestinal tract might cause some reduction in its in vivo absorption rate compared with the B2(solution), which was completely microemulsified before oral administration.

The oral bioavailability of B2(solution) was slightly lower than that for Tricor, but both were lower than that for $\mathrm{Q}($ SMEDDS), and greater than those for B2(SMEDDS) and A2(SMEDDS), which did not significantly differ $(P=0.058)$. This result seems to indicate that the expected difference in the mean particle size after oral administration between B2(SMEDDS) and A2(SMEDDS) as deduced from the in vitro dissolution results did affect the in vivo absorption rate but not the oral bioavailability. However, the oral bioavailability of the B2(solution) formulated by completely microemulsifying B2(SMEDDS) in the same volume of water as that usually taken with oral administration was greater than that for B2(SMEDDS) and only slightly lower than that for Tricor. Therefore, this result might be attributed to the incomplete microemulsification of B2(SMEDDS) and A2(SMEDDS) in the gastrointestinal tract leading to a lower bioavailability compared with B2(solution) that was completely microemulsified before oral administration. As discussed above, the oil content in a higher oil $/ \mathrm{S}_{\text {mix }}$ ratio of $\mathrm{Q}(\mathrm{SMEDDS})$ probably acted as a carrier to provide a favorable additional oral absorption route, such as the lymphatic system, which enhanced both the in vivo absorption rate and the oral bioavailability. Therefore, Q(SMEDDS) with an appropriate ratio of oil/ $\mathrm{S}_{\text {mix }}$ presented the highest oral bioavailability of all SMEDDSs examined and even had an approximately 1.14-1.22-fold higher enhancement over Tricor.

Table 3 Mean pharmacokinetic parameters for B2 and Q self-microemulsifying drug delivery system (SMEDDS) and B2 solution compared with A2 SMEDDS and Tricor $^{\circledR}$ tablets conducted in a previous study ${ }^{36}$

\begin{tabular}{llllll}
\hline $\begin{array}{l}\text { PK } \\
\text { parameters }\end{array}$ & B2 solution & B2 SMEDDS & Q SMEDDS & A2 SMEDDS & Tricor \\
\hline $\mathrm{AUC}_{0 \text {-last }}(\mu \mathrm{g} / \mathrm{mL} \cdot \mathrm{h})$ & $67.02 \pm 20.62$ & $46.85 \pm 19.17$ & $79.48 \pm 5.20$ & $44.81 \pm 14.13$ & $69.75 \pm 12.60$ \\
$\mathrm{AUC}_{0 \text {-inf }}(\mu \mathrm{g} / \mathrm{mL} \cdot \mathrm{h})$ & $78.31 \pm 31.08$ & $51.66 \pm 22.65$ & $106.84 \pm 20.38$ & $52.66 \pm 19.23$ & $87.03 \pm 22.04$ \\
$\mathrm{MRT}_{0 \text {-inf }}(\mathrm{h})$ & $27.06 \pm 9.78$ & $22.54 \pm 4.40$ & $42.85 \pm 18.19$ & $26.30 \pm 9.38$ & $35.15 \pm 8.30$ \\
$\mathrm{~K}_{\mathrm{el}}\left(\mathrm{h}^{-1}\right)$ & $0.036 \pm 0.009$ & $0.040 \pm 0.008$ & $0.025 \pm 0.010$ & $0.039 \pm 0.013$ & $0.027 \pm 0.01$ \\
$\mathrm{~T}_{1 / 2}(\mathrm{~h})$ & $20.28 \pm 5.82$ & $17.94 \pm 3.16$ & $32.04 \pm 13.58$ & $19.73 \pm 6.99$ & $26.43 \pm 5.67$ \\
$\mathrm{CL} / \mathrm{F}(\mathrm{L} / \mathrm{h})$ & $0.78 \pm 0.33$ & $1.21 \pm 0.52$ & $0.52 \pm 0.10$ & $1.14 \pm 0.43$ & $0.65 \pm 0.17$ \\
$\mathrm{~V}_{\mathrm{d}} / \mathrm{F}(\mathrm{L})$ & $21.11 \pm 3.95$ & $31.01 \pm 15.25$ & $22.71 \pm 5.70$ & $29.49 \pm 3.39$ & $23.92 \pm 2.66$ \\
$\mathrm{~T}_{\text {max }}(\mathrm{h})$ & $1.25 \pm 0.50$ & $2.00 \pm 0.82$ & $1.75 \pm 0.50$ & $3.00 \pm 1.41$ & $2.75 \pm 0.50$ \\
$\mathrm{C}_{\text {max }}(\mu \mathrm{g} / \mathrm{mL})$ & $4.29 \pm 0.62$ & $3.21 \pm 1.05$ & $3.74 \pm 0.52$ & $2.62 \pm 0.47$ & $3.27 \pm 0.61$ \\
Bioavailability $(\%)$ & $96.1(90.0)$ & $67.2(59.4)$ & $114.0(I 22.8)$ & $64.2(60.5)$ & $100.0(100.0)$ \\
\hline
\end{tabular}

Note: *Relative bioavailability with respective to Tricor based on $\mathrm{AUC}_{0 \text {-last }}$ or $\left(\mathrm{AUC}_{0 \text {-inf }}\right)$.

Abbreviations: AUC, area under the curve; MRT, mean resistance time; PK, pharmacokinetic. 


\section{Conclusion}

An optimal SMEDDS preconcentrate consisting of Myritol 318 (a medium-chain triglyceride) as the oil phase and TPGS combined with Tween 80 at a ratio of $4: 1$ as the surfactant/ cosurfactant, was able to enhance the oral bioavailability of FFB. Tween 80 was better than Tween 20 in forming smaller particles, which enhanced the in vivo absorption rate by increasing the surface area available for drug dissolution but had little influence on the oral bioavailability due to the lower extent of microemulsification. With a higher oil/ $\mathrm{S}_{\text {mix }}$ ratio exceeding 0.46 , the microemulsification effectiveness (rate) was enhanced making drug particles readily available for absorption at any in vivo agitation rate; the oral bioavailability was improved with the favorable role Myritol 318 might play as a carrier by providing an additional oral route of the lymphatic system for FFB absorption.

\section{Acknowledgment}

Financial support by the National Council of Science of the ROC is highly appreciated (NSC-96-2320-B-038-001).

\section{Disclosure}

The authors report no conflicts of interest, other than the funding mentioned in the Acknowledgment, in this work.

\section{References}

1. Hoar TP, Schulman JH. Transparent water in oil dispersions: oleopathic hydromicelle. Nature. 1943;152:102-105.

2. Spernath A, Aserin A. Microemulsions as carriers for drugs and nutraceuticals. Adv Colloid Interface Sci. 2006;128-130:47-64.

3. Lyons KC, Charman WN, Miller R, Porter CJ. Factors limiting the oral bioavailability of $N$-acetylglucosaminyl- $N$-acetylmuramyl dipeptide (GMDP) and enhancement of absorption in rats by delivery in a waterin-oil microemulsion. Int J Pharm. 2000;199:17-28.

4. Hu ZP, Tawa R, Konishi T, Shibata N, Takada K. A novel emulsifier, Labrasol, enhances gastrointestinal absorption of gentamicin. Life Sci. 2001;69:2899-2910.

5. Kawakami K, Yoshikawa T, Hayashi T, Nishihara Y, Masuda K. Microemulsion formulation for enhanced absorption of poorly soluble drugs. II. In vivo study. J Control Release. 2002;81:75-82.

6. Kang BK, Lee JS, Chon SK, et al. Development of self-microemulsifying drug delivery systems (SMEDDS) for oral bioavailability enhancement of simvastatin in beagle dogs. Int J Pharm. 2004;274:65-73.

7. Sha XY, Yan GJ, Wu YJ, Li JC, Fang XL. Effect of self-microemulsifying drug delivery systems containing Labrasol on tight junctions in Caco-2 cells. Eur J Pharm Sci. 2005;24:477-486.

8. Kommuru TR, Gurley B, Khan MA, Reddy IK. Self-emulsifying drug delivery systems (SEDDS) of coenzyme Q10: formulation development and bioavailability assessment. Int J Pharm. 2001;212:233-246.

9. Spernath A, Yaghmur A, Aserin A, Hoffman RE, Garti N. Self-diffusion nuclear magnetic resonance, microstructure transitions, and solubilization capacity of phytosterols and cholesterol in Winsor IV food-grade microemulsions. J Agric Food Chem. 2003;51:2359-2364.

10. Spernath A, Yaghmur A, Aserin A, Hoffman RE, Garti N. Food-grade microemulsions based on nonionic emulsifiers: media to enhance lycopene solubilization. J Agric Food Chem. 2002;50:6917-6922.
11. Amar I, Aserin A, Garti N. Solubilization patterns of lutein and lutein esters in food grade nonionic microemulsions. J Agric Food Chem. 2003;51:4775-4781.

12. Garti N, Amar I, Yaghmur A, Spernath A, Aserin A. Interfacial modification and structural transitions induced by guest molecules solubilized in U-type nonionic microemulsions. J Disper Sci Technol. $2003 ; 24: 397-410$

13. Garti N, Avrahami M, Aserin A. Improved solubilization of celecoxib in U-type nonionic microemulsions and their structural transitions with progressive aqueous dilution. J Colloid Interface Sci. 2006; 299 : 352-365.

14. Ke WT, Lin SY, Ho HO, Sheu MT. Physical characterizations of microemulsion systems using tocopheryl polyethylene glycol 1000 succinate (TPGS) as a surfactant for the oral delivery of protein drugs. J Control Release. 2005;102:489-507.

15. Pouton CW. Formulation of self-emulsifying drug delivery systems. Adv Drug Deliv Rev. 1997;25:47-58.

16. Holm R, Porter CJ, Edwards GA, Müllertz A, Kristensen HG, Charman WN. Examination of oral absorption and lymphatic transport of halofantrine in a triple-cannulated canine model after administration in self-microemulsifying drug delivery systems (SMEDDS) containing structured triglycerides. Eur J Pharm Sci. 2003;20:91-97.

17. Khoo SM, Humberstone AJ, Porter CJ, Edwards GA, Charman WN. Formulation design and bioavailability assessment of lipidic self-emulsifying formulations of halofantrine. Int J Pharm. 1998;167:155-164.

18. Friman S, Backman L. A new microemulsion formulation of cyclosporine: pharmacokinetic and clinical features. Clin Pharmacokinet. 1996;30:181-193.

19. Kim JY, Ku YS. Enhanced absorption of indomethacin after oral or rectal administration of a self-emulsifying system containing indomethacin in rats. Int J Pharm. 2000;194:81-89.

20. Shen HR, Zhong MK. Preparation and evaluation of self-emulsifying drug delivery systems (SMEDDS) containing atorvastatin. J Pharm Pharmacol. 2006;58:1183-1191.

21. Grove M, MüllertzA, Nielsen JL, Pedersen GP. Bioavailability of seocalcitol II: development and characterization of self-microemulsifying drug delivery systems (SMEDDS) for oral administration containing medium and long chain triglycerides. Eur J Pharm Sci. 2006;28:233-242.

22. Chen Y, Li G, Wu XG, et al. Self-microemulsifying drug delivery system (SMEDDS) of vinpocetine: formulation development and in vivo assessment. Biol Pharm Bull. 2008;31:118-125.

23. Woo JS, Song YK, Hong JY, Lim SJ, Kim CK. Reduced food-effect and enhanced bioavailability of a self-microemulsifying formulation of itraconazole in healthy volunteers. Eur J Pharm Sci. 2008;33: 159-165.

24. Fatouros DG, Nielsen FS, Douroumis D, Hadjileontiadis LJ, Mullertz A. In vitro-in vivo correlations of self-emulsifying drug delivery systems combining the dynamic lipolysis model and neuro-fuzzy networks. Eur J Pharm Biopharm. 2008;69:887-898.

25. Zhang P, Liu Y, Feng NP, Xu J. Preparation and evaluation of selfemulsifying drug delivery system for oridonin. Int J Pharm. 2008; 355 : 269-276.

26. Cooney GF, Jeevanandam V, Choudhury S, Feutren G, Muller EA, Eisen HJ. Comparative bioavailability of Neoral and Sandimmune in cardiac transplant recipients over 1 year. Transplant. 1998;30:1892-1894.

27. Porter CJ, Charman WN. In vitro assessment of oral lipid based formulations. Adv Drug Deliv Rev. 2001;50(Suppl 1): S127-S147.

28. Subramanian N, Ray S, Ghosal SK, Bhadra R, Moulik SP. Formulation design of self-emulsifying drug delivery systems for improved oral bioavailability of Celecoxib. Biol Pharm Bull. 2004;27:1993-1999.

29. Park KM, Kim CK. Preparation and evaluation of flurbiprofen-loaded microemulsion for parenteral delivery. Int J Pharm. 1999;181: 173-179.

30. Munoz A, Guichard JP, Reginault P. Micronised FFB. Atherosclerosis. 1994;110(Suppl):S45-S48. 
31. Stamm A, Seth P, inventors. Fenofibrate pharmaceutical composition having high bioavailability and method for preparing it. United States patent US 6589552. Jul 8, 2003.

32. Guichard JP, Blouquin P, Qing Y. A new formulation of FFB: suprabioavailable tablets. Curr Med Res Opin. 2000;16:134-138.

33. Najib J. FFB in the treatment of dyslipidemia: a review of the data as they relate to the new suprabioavailable tablet formulation. Clin Ther. 2002;24:2022-2050.

34. Sonet B, Vanderbist F, Streel B, Houin G. Randomized crossover studies of the bioequivalence of two FFB formulations after administration of a single oral dose in healthy volunteers. Arzneim Forsch. 2002; 52: 200-204.
35. Patel AR, Vavia PR. Preparation and in vivo evaluation of SMEDDS (self-emulsifying drug delivery system) containing fenofibrate. AAPSJ. 2007;9(3):E344-E352.

36. Wang GM, Chen CH, Ke WT, Ho HO, Sheu MT. Characterizations of fenofibrate dissolution delivered by a self-microemulsifying drug delivery system. J Pharm Pharmacol. 2010;62:1685-1696.
International Journal of Nanomedicine

\section{Publish your work in this journal}

The International Journal of Nanomedicine is an international, peerreviewed journal focusing on the application of nanotechnology in diagnostics, therapeutics, and drug delivery systems throughout the biomedical field. This journal is indexed on PubMed Central,

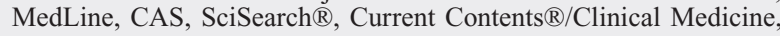

\section{Dovepress}

Journal Citation Reports/Science Edition, EMBase, Scopus and the Elsevier Bibliographic databases. The manuscript management system is completely online and includes a very quick and fair peer-review system, which is all easy to use. Visit http://www.dovepress.com/ testimonials.php to read real quotes from published authors.

Submit your manuscript here: http://www.dovepress.com/international-journal-of-nanomedicine-journal 